\title{
KAMPEN FOR EN OFFICIEL UNDSKYLDNING
}

\author{
Om godhavnssagen som mulighedsrum for erindringsarbejde og kritisk \\ subjektivitet blandt tidligere børnehjemsbørn
}

\section{STINE GRØNB/EK JENSEN}

En lørdag i september 2017 kører omkring 300 motorcykler i samlet flok mod det, som engang var Drenge- og Skolehjemmet Godhavn. De kører turen for at vise deres støtte til Landsforeningen Godhavnsdrengene, som siden 2005 har kæmpet for en officiel undskyldning for den mishandling, de oplevede på danske børnehjem under statens varetægt. Lyden fra de brølende motorer kan høres flere kilometer væk, inden de første motorcykler kører ind i gården, hvor dagens talere står og venter sammen med et større pressekorps. Forrest i kortegen kører en håndfuld tuk-tuk'er af mærket Piaggio Ape - en slags overdækkede knallerter på tre hjul. De larmer ikke helt så meget som motorcyklerne, men tiltrækker sig opmærksomhed med blafrende flag på taget og klistermærker på skærmene. I en tuk-tuk, hvor bagskærmen er dækket af et stort klistermærke med ordene „Giv Godhavnsdrengene en undskyldning!“”, sidder Peter, som i barndommen var anbragt på et børnehjem i Skælskør.

Jeg kender Peter fra flere tidligere møder, hvor han har fortalt mig om sine oplevelser på børnehjemmet og om, hvorfor han støtter Godhavnsdrengenes sag. Han har det ikke særlig godt med at fortælle om sine oplevelser; stemmen dirrer, den vibrerer uroligt mellem hudløs skrøbelighed og vrængende indignation.

Peter har fortalt mig, at han i sine unge år forsøgte at glemme tiden på børnehjemmet. På et tidspunkt smed han alle sine fotografier fra stedet i skraldespanden. Det var først efter et selvmordsforsøg og en indlæggelse, at han erkendte, at han blev nødt til at se fortiden i øjnene, hvis han ville videre i livet. Kort efter så han programmet Drengehjemmet på DR, hvor to mænd fortalte om deres opvækst på Godhavn i 1960'erne præget af vold og medicinske forsøg (Skov 2005). Nogle dage efter læste han i avisen, at de havde dannet en forening. Han gik straks ned på biblioteket, satte sig ved en computer og meldte sig ind. Siden har han været et aktivt medlem af Godhavnsdrengene. 
For Peter har det været af stor betydning, at hans oplevelser på børnehjemmet er blevet bekræftet af de andre foreningsmedlemmer. „Det har givet mig utrolig meget, fordi jeg lige pludselig opdagede, at det ikke bare var mig, der var åndssvag. Vi bærer rundt på de samme oplevelser, de samme ar, de samme laster.“ Et tema, som fylder meget for Peter, er nemlig, at ingen tidligere har lyttet til ham eller troet på ham, når han har forsøgt at fortælle om de overgreb, han var udsat for som dreng. Selv om der var statsligt tilsyn med børnehjemmet, hvor han var anbragt, var der ikke nogen hjælp at hente der: „På et tidspunkt kom der en repræsentant fra børneværnet, og jeg fortalte om nogle af de grimme oplevelser, jeg havde haft, og så går hun sgu hen og spørger min mishandler: 'Kan det nu være rigtigt? Har du gjort det?' Det nægtede han sgu sjovt nok, og så tog hun glad hjem igen. Og imens slæbte mishandleren mig ned i kælderen, råbende, at han kraftedeme nok skulle lære mig at lyve en anden gang, og så fik jeg ellers lært at lyve en anden gang. Og en af de ting, han råbte, det var: 'Du er bare en skide børnehjemsunge. Der er ingen, der gider høre på dig. Du kan skrige og hyle alt det, du vil, men der er ingen, der hører dig'." Mistænkeliggørelse har Peter også oplevet senere i livet: „Tit når jeg i mine unge dage fortalte, at jeg havde været på børnehjem, så kunne jeg mærke, 'nå, så det er sådan en skidt knægt'. Men de fleste af os var sgu ikke skidte knægte ..."

Peters sårbarhed slår over i vrede, og han hæver stemmen, mens han argumenterer for sin holdning til en officiel undskyldning. „Mange spørger: 'Hvad vil du med den undskyldning? Den vil da ikke hjælpe noget ...' Jo, den vil hjælpe noget! Den vil hjælpe mig utrolig meget. Den vil være en anerkendelse af, at det, der skete, var forkert. Den vil være en anerkendelse af, at det, vi har fortalt, er rigtigt. Før vi får den undskyldning, har samfundet ikke erkendt, at det har taget fejl ... Og hver gang en eller anden socialminister siger 'Vi kan ikke give en undskyldning', så stiller hun sig op på ryggen af min mishandler og giver ham ret: 'Der er ingen, der hører på en børnehjemsunge'. “

Denne artikel handler om, hvordan Godhavnsdrengenes kamp for en officiel undskyldning har været med til at skabe et nyt mulighedsrum for bearbejdning af fortiden for tidligere børnehjemsbørn fra Godhavn, men også fra andre børnehjem. ${ }^{1}$

Empirisk tager artiklen afsæt i et omfattende antropologisk feltarbejde på Danmarks Forsorgsmuseum i Svendborg. ${ }^{2}$ Museet har gennem mange år beskæftiget sig med børneforsorgens historie, og derfor får museet ugentligt henvendelser fra mænd og kvinder, som har været anbragt på børnehjem. De mænd og kvinder, som henvender sig, er vidt forskellige, men det er et fællestræk for dem, at de beskæftiger sig aktivt med deres erindringer, og at de i den forbindelse bruger museet enten til at få informationer eller til at gøre deres erfaringer og version 
af historien gældende i offentligheden. Blandt de tidligere børnehjemsbørn, som har henvendt sig til museet, har jeg fulgt omkring 50 særligt tæt. Jeg har interviewet dem på museet eller i deres hjem, men også haft mange uformelle samtaler med dem i telefonen og i forskellige sociale sammenhænge, som jeg har deltaget $\mathrm{i}$ hen over perioden 2013-2019 (Jensen 2019:44ff.). Nogle af de tidligere børnehjemsbørn, som beskæftiger sig aktivt med deres erindringer, kæmper for en officiel undskyldning, men som det vil fremgå, er der også nogle, som mener, at en undskyldning hverken vil gøre fra eller til.

Analytisk trækker jeg i artiklen på erindringsstudier. Jeg belyser den betydning, som den mangeårige kamp for en officiel undskyldning har haft for de tidligere børnehjemsbørns erindringsdannelse, ved hjælp af begrebet erindringssted (Nora 1996), mens jeg begrebsliggør deres aktive beskæftigelse med egen fortid som erindringsarbejde (Jelin 2003). Jeg er samtidig inspireret af antropologiske studier af subjektivitet i min forståelse af erindringsarbejdets kritiske potentiale (Ortner 2005; Biehl 2005; Biehl, Good \& Kleinman 2007; Biehl \& Locke 2010).

Mit argument er, at Godhavnsdrengenes mangeårige kamp for en officiel undskyldning har konstitueret Godhavn som et delt erindringssted i Danmark - det vil sige et omdrejningspunkt for fælles forestillinger og anerkendte fortællinger om fortidens børneforsorg. Jeg hævder, at dette har åbnet et nyt mulighedsrum, hvor tidligere børnehjemsbørn gennem erindringsarbejde er begyndt at artikulere og forholde sig kritisk til erindringer, der før var omgærdet af tavshed, lagret i kroppen og vævet ind i hverdagens væren og relationer til andre. Ved at se erindringsarbejdet som en koncentreret udøvelse af kritisk subjektivitet peger jeg samtidig på, at den enkelte i denne proces potentielt set kan begynde at distancere sig fra og vriste sig fri af fortidens tyngde, men også bruge sine erindringer politisk til fremadrettede formål.

I det følgende skitserer jeg først, hvordan Godhavnsdrengenes kamp for en undskyldning har konstitueret Godhavn som et delt erindringssted, og hvilket nyt mulighedsrum det har skabt for tidligere børnehjemsbørn. Jeg diskuterer herefter min forståelse af erindringsarbejde og kritisk subjektivitet som redskaber til at distancere sig fra og politisere sine erindringer. Gennem to fortællinger viser jeg derefter, hvordan tidligere børnehjemsbørn på forskellige måder gør brug af det nye mulighedsrum, mens de henholdsvis bidrager til og afviser betydningen af en officiel undskyldning i deres forsøg på at bearbejde fortidens fornedrelse.

\section{Godhavn konstitueres som erindringssted}

Da statsminister Mette Frederiksen den 13. august 2019 gav Godhavnsdrengene og andre tidligere børnehjemsbørn en officiel undskyldning for de svigt og over- 
greb, de oplevede under den danske børneforsorg i perioden 1945-1976, var det på baggrund af 15 års politisk kamp drevet frem af Foreningen Godhavnsdrengene. Allerede i 2005 tog foreningens talsmand Poul Erik Rasmussen initiativ til at stifte Landsforeningen Godhavnsdrengene. Med juridisk støtte fra advokaten Bjørn Elmquist var foreningens erklærede mål at få en officiel undskyldning fra den danske stat. Godhavnsdrengene har siden appelleret til samtlige socialministre om en officiel undskyldning. Som respons på de mange afslag fra politisk hold har foreningen samtidig forsøgt sig ad rettens vej. For at prøve sagen på vegne af tidligere børnehjemsbørn og andre anbragte i statens varetægt anlagde Poul Erik Rasmussen i 2015 sag mod staten. På baggrund af anklager om torturlignende forhold på Godhavn i strid med Den Europæiske Menneskerettighedskonvention og FN's konvention mod tortur søgte han om symbolsk erstatning på mindstebeløbet 10.001 kroner. Sagen, der blev forsvaret af Kammeradvokaten, faldt dog for den femårige forældelsesfrist først i Byretten og siden i Landsretten (Danmarks Domstole 2015, 2017).

Trods gentagne afslag om en officiel undskyldning og nederlag i retten har Godhavnsdrengene haft en imponerende gennemslagskraft i offentligheden. Deres fortællinger har trukket massiv opmærksomhed i medierne under overskrifter som „Rædslerne fra fortiden forfølger dem stadig“ (Eriksen 2017), og deres kamp er på mange måder blevet båret frem af en række erindringsbærende kulturelle aktører. Ikke mindst har DR's tv-dokumentar Drengehjemmet (Skov 2005) haft en stor betydning. I Drengehjemmet følger vi to tidligere børnehjemsbørn fra Godhavn, som under et genbesøg fortæller om deres oplevelser med tæsk, ydmygelser, medicinering med psykofarmaka og om de sociale og psykiske følger, som anbringelsen har haft for deres videre liv. Dokumentaren affødte omfattende kritik og debat i medierne, og på den baggrund afsatte Socialministeriet i 2009 midler til en uvildig granskning af klager rejst af Godhavnsdrengene. Undersøgelsen blev varetaget af Danmarks Forsorgsmuseum i Svendborg og blev afsluttet med Godhavnsrapporten (Rytter 2011). Rapporten dokumenterer en udbredt anvendelse af særdeles hårdhændede fysiske afstraffelser, som var ulovlige, da de fandt sted, ydmygende behandling af sengevædere og seksuelle overgreb. Ligeledes påvises mangelfuld undervisning, urimelig meget og hårdt arbejde, dårlig kost, utidssvarende beklædning, isolation fra det omkringliggende samfund og familien samt mangelfuldt statsligt tilsyn. Rapporten påpeger desuden, at psykiateren tilknyttet Godhavn i behandlingen af blandt andet sengevædning forsøgte sig frem med stærke antipsykotiske præparater velvidende, at de var afhængighedsskabende og kunne medføre stærke bivirkninger. I et afsluttende kapitel beskrives fundet af en gymnastikhest fra Værebro Drengehjem, som ifølge en tidligere anbragt på børnehjemmet blev brugt til fysiske afstraffelser. Med kriminalpolitiets 
hjælp blev der fundet indikation på blodstænk over det meste af hesten. Bevidste om hestens symbolske værdi som et bevis, der kunne understøtte de tidligere børnehjemsbørns beretninger som troværdige og sandfærdige, fik hesten en central placering ikke bare i rapporten, men også på museets børnehjemsudstilling (ibid.; Rytter \& Rasmussen 2015:11f.).

Senere blev interessen for Godhavnsdrengenes fortælling yderligere cementeret med fiktive bearbejdninger af historien om Godhavn. Først med udgivelsen af Ole Tornbjergs roman Drengen fra Godhavn (Tornbjerg 2015). Året efter med spillefilmen Der kommer en dag (Nielsen 2016). I filmen, hvor de bærende roller spilles af berømmede skuespillere som Sofie Gråbøl og Lars Mikkelsen, følger vi to brødre, som i slutningen af 1960'erne anbringes på et børnehjem, der styres med hård hånd og nedbrydende disciplin. Skønt børnehjemmet i filmen kaldes Gudbjerg, fremhæves det i markedsføringen af filmen såvel som af rulleteksten, at den er baseret på virkelige hændelser og tager afsæt i Godhavnsdrengenes fortællinger. To måneder efter premieren havde filmen solgt mere end 200.000 billetter, og filmen høstede en række Robertpriser, blandt andet for årets film. Året efter i 2017 blev Der kommer en dag vist som miniserie på TV2 i den bedste sendetid.

Et paradoks er knyttet til Godhavnsdrengenes kamp. På den ene side har de gentagne afvisninger af en officiel undskyldning fra skiftende regeringer manifesteret Godhavnsdrengenes position som børnehjemsbørn, hvis lidelser skiftende repræsentanter for staten måske nok kunne beklage, men ikke tage ansvar for. På den anden side har afvisningerne positioneret den danske stat som en ideel fjende, der først svigtede sit tilsyn og senere nægtede at påtage sig et ansvar. Denne positionering er blevet understøttet af medier og kulturelle aktører, men skyldes også, at Godhavnsdrengenes krav om en officiel undskyldning kontinuerligt er blevet holdt op mod andre vestlige lande, hvor tidligere børnehjemsbørns forsøg på at få staten til at påtage sig et ansvar for svigt og overgreb allerede i starten af 00'erne blev imødekommet af udredninger, officielle undskyldninger og i flere lande - herunder vores nordiske nabolande - økonomisk kompensation (Skjöld 2015:22).

Jeg vil hævde, at godhavnssagen på grund af dette paradoks har fået en særlig symbolsk kraft, som har været medvirkende til at etablere Godhavn som et erindringssted i overensstemmelse med den franske historiker Pierre Noras brug af begrebet (lieux de mémoire). Det vil sige et fælles symbolsk orienteringspunkt i den delte erindring, hvorom viden, men også forestillinger, følelser, betydninger og engagement koncentrerer sig (Nora 1996). Som erindringssted symboliseres Godhavn gennem en lang række stærke billeder: en halvnøgen frysende dreng stående i gården med et vådt lagen, drenge i slidt blåt arbejdstøj med bare 
fødder i træsko, en stor kold sovesal med tremmesenge på snorlige rækker, en gymnastikhest med blodpletter, ord som „Godhavnsbank“ og ,sjæleknuserfabrikken", fotografier af ældre mænd med furede ansigter stående med et blåt banner foran en retssal eller et folketing som en David foran en Goliat. Det er blandt andet i det lys, at vi skal forstå, hvorfor 300 motorcyklister larmende kører til Godhavn i samlet flok for at vise deres støtte til kampen for Godhavnsdrengenes sag. Som fælles erindringssted repræsenterer Godhavn nemlig meget mere end det, der hændte på et specifikt børnehjem i Tisvildeleje i 1960'erne. Som erindringssted handler Godhavn om et samfund, der har svigtet de allermest udsatte, men også om, hvordan de engang udsatte børn i fællesskab nu rejser sig og hæver deres stemmer.

Som erindringssted har Godhavn samtidig skabt en særlig erindringspolitisk kontekst for tidligere børnehjemsbørn, som udgør et nyt mulighedsrum, hvor det er blevet lettere at artikulere, reflektere over, offentliggøre og politisere smertefulde erindringer, som meget af livet har været fraværende eller holdt ude af bevidstheden. Først og fremmest har den pågående debat om svigt, misrøgt og overgreb på efterkrigstidens institutioner været med til at give deres erindringer en relevans og aktualitet i samfundet. Erindringer, som kun få har interesseret sig for, og som måske derfor er gledet i baggrunden af bevidstheden $i$ årevis, er pludselig blevet genstand for intens interesse. Der er med andre ord blevet skabt et offentligt rum, hvor andre er villige til at lytte til, tro på og tage del i de tidligere børnehjemsbørns erindringer og lidelser. Tidligere børnehjemsbørn har samtidig fået en ny position at tale fra, ikke kun som ofre, men også som historiske vidner og politiske aktører, hvis historier har en moralsk værdi, der vedkommer andre. Etableringen af nye fællesskaber blandt tidligere børnehjemsbørn - blandt andet på de sociale medier - har også givet nye muligheder for udveksling og dannelse af delte erindringer, hvor det har været legitimt at give udtryk for stærke følelser som sorg, vrede og bitterhed, og hvor der er blevet skabt en fælles identitet. Etableringen af Godhavn som delt erindringssted har desuden givet en ny betydningsramme og tilgængeliggjort anerkendte ord og fortællinger om overgreb og svigt, som har gjort det lettere at artikulere smertefulde og risikable erindringer og omfortolke deres betydning. Især har godhavnssagen gjort det muligt at vriste sig fri af individuelle bebrejdelser og skam for i stedet at placere skylden hos børnehjem og staten.

Når mange tidligere børnehjemsbørn begynder at artikulere og forme deres erindringer i et tæt samspil med fortællingen om Godhavn, kan dette naturligvis fortolkes som udtryk for, at personlige erindringer tilpasses en ny dominerende diskurs. En sådan tilgang til erindringsdannelse er udbredt, både i erindringsstudier generelt og i studier af samspillet mellem tidligere børnehjemsbørns per- 
sonlige erindringer og tilgængelige fortællinger om børneforsorgen i offentligheden (Green 2004; Murphy 2010; Edwards 2017). Som vidne til de tidligere børnehjemsbørns erindringsarbejde og livtag med både den personlige og fælles historie er jeg dog gentagne gange blevet slået af den refleksion, kreativitet og sociale kritik, som ligger indlejret i deres forsøg på at skabe mening med og håndtere deres erindringer og gøre dem gældende i offentligheden - det vil sige deres agens. I det følgende vil jeg se nærmere på denne agens ved at pege på, hvordan erindringsarbejde kan transformere erindringernes karakter og aktivere en kritisk subjektivitet.

\section{Erindringsarbejde som udøvelse af kritisk subjektivitet}

Som allerede nævnt er det et fællestræk for de tidligere børnehjemsbørn, som gennem de senere år har kontaktet Danmarks Forsorgsmuseum, at de beskæftiger sig indgående med deres personlige historie og erindringer. De søger om indsigt i egne journaler, de opsøger steder og mennesker fra barndommen, de skriver deres erindringer ned, og mange forsøger også at gøre deres version af historien gældende i offentligheden. Flere af de tidligere børnehjemsbørn, som jeg har talt med, beskriver denne beskæftigelse metaforisk som en rejse; som „min rejse hjem til mig selv“ eller „min rejse ind i fortiden“. For de fleste er rejsen forbundet med et håb om at få en større forståelse af, hvorfor de er blevet, som de er, og hvorfor livet har formet sig for dem, som det har, men også at gøre omverdenen opmærksom på den uretfærdighed, de er blevet udsat for, og måske hjælpe andre, som befinder sig i lignende situationer i dag. De ønsker med andre ord at ændre deres forhold til fortiden, men også at ændre sig selv og den sociale omverden.

Analytisk ser jeg de tidligere børnehjemsbørns beskæftigelse med egne erindringer som et erindringsarbejde, hvor arbejde refererer til processer, der tilfører verden noget bearbejdet og dermed nyt. Jeg er her inspireret af Elizabeth Jelins definition af erindringsarbejde som noget, der positionerer mennesket som „en transformerende aktør" (Jelin 2003:5). I sin begrebsliggørelse af erindringsarbejde skelner Jelin analytisk mellem to måder at erindre på. På den ene side kan erindringer være nærværende i nutiden uafhængigt af vores bevidsthed og vilje, og uden at de gøres til genstand for arbejde. Her peger Jelin især på traumatiske erindringer, som er omgærdet af stilhed, men som også invaderer og forstyrrer nutiden uden at give mening. Ifølge Jelin er der tale om „et nærvær uden agens“ (ibid.). I modsætning hertil ser hun erindringsarbejdet som udtryk for agens. Jelins pointe er, at mennesker gennem erindringsarbejdet kan distancere sig fra og bearbejde de invaderende erindringer og hermed frigøre sig fra dem. Samtidig overfører Jelin denne psykoanalytiske forståelse af sorgbearbejdning til den of- 
fentlige og politiske sfære, idet erindringsarbejdet også kan involvere en forhandling af forholdet mellem erindring, politik og retfærdighed. Gennem erindringsarbejde kan mennesker skabe en distance til deres smertelige erindringer, men de kan også i processen blive etiske og politiske aktører (op.cit.6f.).

Jeg deler Jelins forståelse af erindringsarbejdets transformerende karakter. Men jeg vil samtidig nuancere den forståelse, der gør sig gældende, når Jelin skelner mellem en ubevidst og passiv erindring på den ene side og en bevidst og aktiv erindring på den anden. I stedet mener jeg, at der er tale om forskellige former for aktiv erindringshåndtering. Eksempelvis har antropologen Veena Das vist, at også tavshed og det at gemme det ubærlige væk i kroppen kan anskues som en aktiv håndtering af lidelse i forsøget på at fortsætte og leve sit liv. Som det fremgår af undertitlen på hendes bog Life and Word. Violence and the Descent into the Ordinary, undersøger Das, hvordan smertelige erindringer finder andre udtryk end sproglige og væver sig ind i det almindelige, ind i hverdagens levede liv og relationer (Das 2007).

Frem for at se erindringsarbejdet som en transformering fra passiv til aktiv erindring ser jeg erindringsarbejdet som en praksis, hvorigennem kropslige og levede erindringer kan få en ydre form. Tidligere børnehjemsbørn bærer som alle andre deres erindringer med sig i kroppen og i de måder, de lever og sanser på. Gennem erindringsarbejdets mange forskellige praksisser gøres nogle af disse kropslige erindringer imidlertid til genstand for fortællinger og materialiseringer, hvormed de yderliggøres som repræsentationer (Jensen 2019:25).

Erindringsarbejdets transformerende processer er naturligvis tæt forbundet med, hvad der er muligt og ikke muligt at sige i det omgivende samfund, og hvorvidt der findes sproglige forudsætninger i form af mere eller mindre legitime ord og anerkendte fortællinger, som kan bruges til at artikulere egne erindringer med (Jelin 2003:xv; Das 2007:38f.). Den erindringshistoriske kontekst og de fælles forestillinger om og holdninger til fortiden er således en væsentlig ramme om erindringsarbejde.

Jeg mener dog også, at det er væsentligt at se på, hvordan erindringsarbejde samtidig indebærer en mulighed for at skabe social forandring. Jeg henter her inspiration fra antropologiske studier, som har rejst kritik af oversocialiserede forståelser af subjektivitet, og som har forsøgt at udvikle mere komplekse og dynamiske teorier (Ortner 2005; Biehl 2005; Biehl, Good \& Kleinman 2007; Biehl $\&$ Locke 2010). Inden for disse studier er der en anerkendelse af, at det enkelte menneske ikke kan stille sig uden for historien og kulturen og dens dominerende diskurser, men de ser samtidig subjektivitet som sammensat af mange lag, hvilket muliggør refleksion og kritik af den verden, vi befinder os i (Ortner 2005:46). Med udgangspunkt i denne forståelse af subjektivitet mener jeg, at de tidligere 
børnehjemsbørns erindringsarbejde kan betragtes som en koncentreret udøvelse afkritisk subjektivitet (Jensen 2019:27). Gennem erindringsarbejdets transformerende processer, hvor kropslige erindringer får en ydre form, bliver det muligt for de tidligere børnehjemsbørn at distancere sig fra, reflektere over og kritisere måderne, hvorpå de er blevet behandlet, kategoriseret, formet eller subjektiveret som „børnehjemsunger“. Erindringsarbejde kan hermed aktivere en subjektivitet, der gør det muligt at træde ud i det offentlige rum med en kritisk stemme, der udfordrer stilhed og glemsel, rokker ved vores fælles forestillinger om fortiden og gør egne erfaringer gældende som et fælles etisk anliggende.

\section{„Menneskelig igen“}

Peer er en spinkel mand i begyndelsen af 60'erne med halvlangt hår, lædervest og en stemme slebet af det indre Vesterbro, hvor han voksede op i en etværelses lejlighed i en baggård til Absalonsgade. Gennem barndommen var han samtidig anbragt på en lang række spædbørnshjem, observationshjem, børnehjem og opdragelseshjem. „Svingdørsanbragt“ kalder han sig selv. Da Peer blev udskrevet fra børneforsorgen, fortsatte han med at leve et omflakkende liv og forsøgte at flygte fra de ting, han havde oplevet, ,og så har man jo enten været på morfinbasen, eller også har man gået på landevejene og drukket sig stangstiv for at glemme det". Om vinteren overnattede han på sofaer rundtomkring hos bekendte, og om sommeren overnattede han ude eller i tomme lader. Når det var koldt, satte han sig ind på et bibliotek og konstruerede krydsord, som han solgte til ugeblade som for eksempel Hjemmet.

For Peer kom den aktive deltagelse i Godhavnsdrengenes kamp for en officiel undskyldning til at betyde, at han begyndte at forholde sig til og tale om de ting, han havde oplevet på skiftende børnehjem. Det betød også, at han fik kontakt til Danmarks Forsorgsmuseum og under flere møder fortalte mig om sine erfaringer fra barndommen. Men der var også nogle ting, han ikke ville ind på. Ikke før en søndag morgen, hvor jeg modtog en lydfil, som han havde optaget på sin telefon. På optagelsen fortæller han om de seksuelle overgreb, som lægen på Børnehjemmet Blide omkring 1960 udsatte ham for, da han var helt lille. Peer henvender sig ikke til mig. Han taler til sig selv og med sig selv. Han siger ting som: „Det må du sgu indrømme Peer.“ På optagelsen konfronterer han sig selv med noget af det, som han livet igennem har levet med, men som han først nu er blevet i stand til at omsætte til ord. Man kan høre på hans stemme og måden, hvorpå han snubler over ordene, at han har drukket sig mod til.

Omkring et halvt år senere den 30. januar 2017 sidder Peer sammen med flere af de andre Godhavnsdrenge på Christiansborg for at følge Folketingets 2.-behand- 
ling af et lovsforslag om ophævelse af forældelsesfrister for strafansvar i sager om seksuelt misbrug af børn og om erstatningskrav over for forvaltningsmyndigheder for svigt i sager om overgreb mod børn. Det er en sag, foreningen har kæmpet for og bakket op om. Ikke alene vil lovændringen muliggøre deres egen sagsøgning af staten, da forslaget er med tilbagevirkende kraft, en lovændring vil også forbedre børns retssikkerhed generelt. Så da lovforslaget rejses, og samtlige fremmødte politikere i salen stemmer ja, er det en sejr for foreningen.

Morgenen efter skriver Peer et opslag i Facebook-gruppen Foreningen Godhavnsdrengene: „Jeg tror, at jeg i går på nettet op til 10 gange i løbet af eftermiddagen/aftenen/natten fik skrevet at 'nu gik jeg i seng', men det var først klokken 00.23, at jeg fik taget mig sammen til at lukke 'comporen' ned, og som det mest naturlige i verden fik taget mit tøj af, inden jeg trissede over til sengen. Det var først, da jeg sad på sengekanten, at det gik op for mig, at det var første gang, siden jeg flyttede ind i min nuværende lejlighed i august 2004, at jeg ikke skulle argumentere med mig selv for at få det åndssvage tøj af. Jeg må erkende, at jeg forholdvis tit herhjemme om morgenen finder mig selv liggende fuld påklædt oven på dynen. Det ender sgu nok med, at jeg ligefrem bliver menneskelig igen. Og det kan jeg blandt andre takke alle jer herinde for. Hilsen og tanker Peer.“

Peers historie viser, hvordan Godhavnsdrengenes kamp for en officiel undskyldning $i$ en gensidig bevægelse har medført transformationer af den omgivende sociale verden og medlemmernes subjektivitet. Forandringerne hos den enkelte illusteres hos flere gennem stærke tilkendegivelser om kampens betydning, men også i mere subtile fortællinger, som det er tilfældet hos Peer. Hos Peer har godhavnssagen igennem flere år været omdrejningspunkt for et omfattende erindringsarbejde, som har aktiveret en kritisk subjektivitet, der har gjort det muligt for ham at artikulere de erindringer, han har båret på gennem livet, og reflektere kritisk over den måde, han er blevet misbrugt og formet på. Ligeledes har godhavnssagen givet ham adgang til et nyt fællesskab, hvor han sammen med ligestillede bruger sine erindringer politisk i en meningsfyldt kamp for større retfærdighed og rent faktisk bidrager til at udligne uretfærdigheder i den sociale verden.

Vi ser samtidig, hvilken betydning det kan have, når statens repræsentanter lytter til og anerkender tidligere og nuværende anbragtes erfaringer og påtager sig et klart ansvar. Når Peer ikke behøver at diskutere med sig selv, inden han tager tøjet af, hænger det formodentlig sammen med en fornyet fornemmelse af, at han ikke bare er et offer for andres handlinger, men også en aktør, der sammen med andre kan gøre en positiv forskel i verden. Men det hænger også sammen med nogle lidt mere positive forventninger til det omgivende samfund, hvormed behovet for at beskytte sig selv mod andre og det sociale fællesskab mindskes. 
Gennem kampen for en officiel undskyldning og de små sejre undervejs er det således ikke bare Peers syn på sig selv og den sociale omverden, der forandrer sig, det er også hans subjektivitet, hans måde at være i verden på, som ændrer sig $\mathrm{i}$ en retning, som han selv forbinder med at blive „menneskelig igen“. I det følgende vender jeg opmærksomheden mod Poul, som afviser betydningen af en officiel undskyldning.

\section{"Samfundet kan ikke fjerne min bitterhed“}

I nogle uger lå det manuskript, som Poul Hansen havde indleveret til museet, på mit skrivebord. Fotografiet på forsiden viser en otte-ni-årig dreng i en lidt for lille skjorte og et par korte bukser i kraftigt, falmet stof. Han har bare fødder og ser genert op på fotografen. Håret er pjusket, klippet skævt. Over billedet står der: „Et akavet liv!“ Da jeg havde læst Pouls beretning, ringede jeg til ham og spurgte, om han ville komme ned på museet igen og fortælle mere om sine erindringer. Han kom på motorcykel en mørk efterårsdag i øsregnvejr. Jeg husker det, som om vandet nærmest drev af lædertøjet, som vi hængte op hen over nogle stole ved radiatoren.

„Hvorfor har du kaldt dine erindringer 'Et akavet liv!'“, spørger jeg som det første, mens kaffen damper fra kopperne mellem os. „Det ved jeg sgu ikke rigtig,“ siger han og lader hånden glide hen over det lange skæg, ,men det er vel, fordi jeg synes, mit liv har været akavet. Bortset fra andre børnehjemsfyre som mig så kender jeg ingen, der har været så akavede med alting. “

Poul starter med at fortælle, at meget i den nedfældede beretning først er noget, han har fundet ud af, da han som voksen begyndte at granske i sin egen historie. Han vidste ikke engang, at han havde en storesøster, som også var anbragt på Bolbro Børnehjem samtidig med ham. Først senere mødte han flere af sine ældre søskende. At hans far var tysk soldat, var også først noget, han fik kendskab til sent i livet.

Samtidig er der flere erindringer, som har fulgt Poul livet igennem. „De mange gange, man fik tæsk, det vender tilbage. Jeg kan ikke huske ret meget positivt, det er, som om det er blevet skubbet i baggrunden af alle de der situationer, hvor jeg blev behandlet groft.“ Poul husker især fra den helt tidlige barndom, hvordan plejemoren på Bolbro flere gange hentede ham ind i sin lejlighed fra sovesalen om aftenen for at give ham tæsk. ,Jeg husker ikke, jeg havde gjort noget forkert. Jeg blev bare hentet ind, og så morede hun sig åbenbart med det.“ Poul fortæller, at han ofte har „flashbacks“ relateret til de situationer, og at de giver ham ,et koldt, koldt gys“. 
Tiden på Holsteinsminde, hvor Poul var blevet nogle år ældre, var præget af hårdt arbejde og bøn morgen, middag og aften, mens „øretæverne hang i luften“. Det sværeste for Poul var imidlertid visheden om, at han ikke var elsket af nogen, og han misundte de børn, som gik og snakkede om deres forældre, som fik tilsendt pakker, og som kom hjem på ferie. ,Jeg kan huske sådan en åndssvag episode ... Om efteråret så falder bladene jo ned fra træerne, og så gik myten, at hvis man fangede et blad i luften, så kom man hjem til jul. Og det forsøgte jeg også ... hvor idiotisk ..." Poul bliver stille og tager hænderne op foran ansigtet, mumler noget med ,gammelt fjols“" og siger, at det lige var det her, han gerne ville undgå. Lidt efter retter han sig op og fortsætter: „Dum og naiv, som jeg var, så fangede jeg blade, og når de andre snakkede om, at de skulle hjem til jul eller påske, så snakkede jeg med, og så var der en af de andre drenge, der godt kunne finde på at sige: 'Du skal sgu da ikke nogen steder hen.' Så fik den dreng et par på hovedet lige med det samme. Så enkelt var det bare. Det skulle han ikke begynde på.“

I det hele taget havde Poul en kort lunte, og han forklarer, at det var hans måde at overleve på. ,Altså, hvis du slår først, har du chancen for at være den, der vinder. Og det har reddet mig mange gange, for det fik de andre til at holde lidt igen. Men i det hele taget - alt blev afgjort rent fysisk, også hos de der lærere eller oppassere, vi havde, så det var den måde, jeg kendte til.“ Poul fortæller, at den korte lunte varede ved, også efter at han forlod børnehjemmet. „Som ung mand, der reagerede jeg meget udadvendt, lad os sige det sådan. Og jeg var følsom ad helvede til over for, hvad andre sagde og gjorde, og så sagde det bang, så fik de en på skallen først, og så kunne vi snakke om det bagefter.“

Poul siger, at han også havde nogle andre mærkelige måder at reagere på. „Hvis der var nogen, der svinede mig til eller forsøgte at tæve mig, det var jeg vant til, det rørte mig en papand, men hvis der var nogen, der holdt med mig eller sagde noget pænt om mig, det kunne jeg slet ikke tåle, og det hænger jo på stadigvæk." Poul husker især engang, han steg på rutebilen ved børnehjemmet, og en ældre mand begyndte at håne ham for at være børnehjemsunge. „Han blev mere og mere grov i sin mund. Og så på et tidspunkt stoppede rutebilchaufføren og smed manden af. Simpelthen." Poul bliver så rørt over at fortælle om buschaufførens uventede støtte, at han banker hånden hårdt ned i bordet og tager sig til hovedet. „Der har vi den igen,“ siger han, ,jeg kan ikke tåle det ... så sidder jeg her og flipper ud." Poul sunder sig og fortæller, at han er vokset op med, at hvis man blev følsom, så viste man svaghed, og så var man udsat, så han har altid forsøgt at gøre sig hård.

Det var en stor ting for Poul at blive far og få den familie, som han altid havde drømt om, men det var ikke uden vanskeligheder. Efter at han blev skilt fra sin kone, blev børnene hos ham, og det gik så nogenlunde, men han syntes, det var 
svært at vise dem sine følelser. „Og et eller andet sted,“ siger han, „så kunne jeg jo lige så godt være blevet ærkepsykopat, sådan hel følelseskold ... Det er underligt, at man egentlig skal spekulere i den slags. En ganske almindelig person ville jo aldrig sidde som 70-årig og tænke: Hvordan har jeg egentlig fået evnen til at elske mine egne børn?"

Hos Poul fylder bitterheden meget i livet. „Jeg synes rent ud sagt, at det er noget forbandet svineri, som man opførte sig over for os dengang," siger han vredt, men han giver samtidig udtryk for, at han har lært at leve med bitterheden og ikke tror, at han nogensinde kommer af med den. „Det er også derfor, jeg ikke forstår Godhavnsdrengene. Jeg har tit tænkt over, hvad fanden skal de bruge den til, hvad fanden skal en undskyldning hjælpe? De mennesker, som gjorde det dengang, de er her jo ikke mere. Samfundet kan ikke undskylde for noget, som andre mennesker har gået og lavet. Samfundet, det er bare et begreb. Samfundet kan ikke sige undskyld og fjerne min bitterhed.“ Til gengæld fortæller Poul, at det måske ville gøre en forskel, hvis han fik en økonomisk kompensation ,som kunne bruges til at forsøde tilværelsen“.

Godhavnsdrengenes kamp for en officiel undskyldning har på mange måder gjort det lettere for Poul at skrive sine erindringer ned og forholde sig kritisk til dem. Godhavnssagen har således også for Poul åbnet et mulighedsrum. Det betyder dog ikke, at Poul køber præmissen om, at en officiel undskyldning ville ændre ved noget. Når Poul og flere andre afviser betydningen af en moralsk undskyldning og i stedet fremhæver relevansen af en konkret økonomisk kompensation, skal det blandt andet ses i lyset af, at mange tidligere børnehjemsbørn med en opvækst i statens varetægt har en dårlig økonomi. Det skyldes blandt andet manglende uddannelse, vanskeligheder ved at fastholde et job og store udgifter forbundet med at håndtere barndommens svigt gennem stimulanser eller terapi (Simonsen \& Pettersen 2015). Men afvisningen af forestillingen om, at en officiel undskyldning ville ændre noget som helst, handler også om en afstandtagen fra den åbenhed for forsoning, som en accept af en undskyldning indebærer fra de tidligere børnehjemsbørns side (Pettersen 2011:63-66). Budskabet hos Poul og flere andre, som afviser en undskyldning, synes at være, at glemsel, men også forsoning er det samme som en accept af den nedgørelse og degradering, som overgrebene var udtryk for.

For Poul synes afvisningen dog samtidig at handle om, at muligheden for transformationer af hans subjektivitet - i retning af en større tiltro til andre og den sociale omverden - først og fremmest knytter sig til reaktioner fra nogle helt konkrete mennesker, som han møder i sit liv, eksempelvis buschaufføren. I forlængelse heraf er det en væsentlig del af Pouls livshistorie, at han i slutningen af sin tid på børnehjemmet etablerede en kontakt til en ældre dame, der arbejdede på 
børnehjemmets vaskeri, og at han gennem hende knyttede et nært og livslangt venskab til hendes søn og svigerdatter, som kun er få år ældre end ham. Poul fortæller, at han ikke har mange venner og generelt har meget svært ved at stole på andre og tro på, at de vil ham noget godt. Poul tøver derfor ikke med at beskrive dette venskab som det, der har gjort ham til ,et helt menneske“.

\section{Konklusion}

I artiklen har jeg vist, hvordan Godhavnsdrengenes lange kamp for en officiel undskyldning har bidraget til etableringen af en delt erindring centreret om Godhavn, som med sin stærke symbolske kraft har ændret landskabet for alle tidligere børnehjemsbørns erindringsdannelse - uanset deres holdninger til undskyldningen i øvrigt. Mange er således de senere år begyndt at beskæftige sig aktivt med deres erindringer, og jeg har argumenteret for, at dette erindringsarbejde kan ses som en udøvelse af kritisk subjektivitet, hvormed den enkelte kan begynde at forholde sig kritisk til sine erindringer og bruge dem politisk.

De tidligere børnehjemsbørn, som gennem snart mange år har kæmpet for en officiel undskyldning, deler et håb om, at den uretfærdighed, de har været udsat for, kan mindskes, hvis samfundets øverste repræsentanter anerkender, at overgreb fandt sted, og at samfundet og staten har et ansvar. Det kommer blandt andet til udtryk hos Peter fra artiklens indledning. Hos Peter retter indignationen sig ikke kun mod konkrete gerningsmænd. Den retter sig også mod samfundets indlejrede magtforhold og hierarkier, som muliggjorde, at han blev anbragt og udsat for overgreb og senere stigmatiseret som en ,skidt knægt“. I Peters fortælling legemliggør overgrebsmanden samfundets svigt, mens skiftende socialministre, der gerne beklager i vage vendinger, men ikke vil give en egentlig undskyldning, personificerer samfundets ligegyldighed, fordi han bare er ,en skide børnehjemsunge“". Peter håber derfor, at samfundet gennem en officiel undskyldning vil anerkende rigtigheden og alvoren af hans erfaringer, påtage sig et ansvar og gennem et moralsk selvopgør ophæve den sociale degradering. Ifølge Peter vil dette give ham en mulighed for at træde ud af sin isolation og genvinde en vis tillid til andre og det sociale fællesskab, han indgår i. Peters fortælling illustrerer betydningen af en officiel undskyldning. Men den illustrerer i høj grad også betydningen af at kæmpe for den. Med godhavnssagen som afsæt for erindringsarbejde ændrede meget sig for Peter, Peer og mange andre tidligere børnehjemsbørn også inden undskyldningen faldt. Ligeledes har deres kamp betydet, at meget har ændret sig i vores fælles forestillinger om den danske velfærdsstats historie.

Artiklen viser samtidig, at ikke alle var parate til at acceptere den undskyldning, som statsministeren gav i 2019. Når betydningen af en officiel undskyldning 
afvises, handler det blandt andet om en manglende tiltro til, at symbolske ord kan ændre ved de lidelser, som hårdtslående hænder har forvoldt, men også en manglende tiltro til den sociale omverden og i særdeleshed samfundets officielle repræsentanter. Dette ændrer dog ikke ved, at godhavnssagen også har givet Poul og andre med lignende holdninger nye muligheder for at artikulere smertelige erindringer, forholde sig kritisk til dem og omdanne personlig skam til social indignation.

Det er samtidig vigtigt at nævne, at der også er flere, som overvejende har gode erindringer fra en barndom på børnehjem. Nogle af dem oplever, at godhavnssagen har skabt et ensidigt fokus på overgreb og svigt under børneforsorgen i det offentlige rum, som truer de fortællinger, de har fortalt sig selv og andre gennem livet, og som betyder, at de ofte mødes af en forventning om, at de som tidligere børnehjemsbørn må være psykisk skadede. Også flere tidligere børnehjemsbørn med en god opvækst på børnehjem er således gået i gang med at beskæftige sig aktivt med deres erindringer i et forsøg på at værne om deres selv, men også for at nuancere de seneste års fokus på de mørkeste sider af datidens børneforsorg.

Den delte erindring konstitueret omkring godhavnssagen har åbnet nogle nye muligheder for at artikulere kropslige erindringer, skabe mening med dem og bruge dem politisk, men godhavnssagen har også gjort det sværere at få lydhørhed i forhold til andre former for erindringer, andre måder at skabe mening med dem på og andre former for politiske krav end undskyldningen. Ved at fokusere på de tidligere børnehjemsbørns erindringsarbejde og kritiske subjektivitet tydeliggøres det imidlertid, at mulighedsrummet hverken er statisk eller fuldstændig dominerende. Derimod er det i konstant bevægelse og til stadig forhandling, og tidligere børnehjemsbørn bruger det både kreativt, refleksivt, selektivt og kritisk i deres forsøg på at transformere både den personlige og den fælles historie.

\section{Noter}

1. Artiklen er baseret på min ph.d.-afhandling At åbne skuffen (Jensen 2019).

2. Det empiriske feltarbejde blev gennemført i forbindelse med mit ph.d.-projekt, som var forankret på Danmarks Forsorgsmuseum 2015-2019, men jeg trækker også på empiri fra et tidligere forskningsprojekt på museet, kaldet „Anbragt i historien“, som blev gennemført 2013-2015 og mundede ud i bogen På kanten af velfcerdsstaten (Kragh et al. 2015). 


\section{Litteratur}

Bell, Christine

2009 Transitional Justice, Interdisciplinarity and the State of the "Field" or "Non-Field". The International Journal of Transitional Justice 3(1):5-27.

Biehl, João

2005

Vita. Life in a Zone of Social Abandonment. Berkeley: University of California Press.

Biehl, João \& Peter Locke

2010 Deleuze and the Anthropology of Becoming. Current Anthropology 51(3):317-51.

Biehl, João, Byron Good \& Arthur Kleinman

2007 Introduction. Rethinking Subjectivity. In: J. Biehl, B. Good \& A. Kleinman (eds): Subjectivity. Ethnographic Investigations. Berkeley: University of California Press.

Danmarks Domstole

2015 Dom i Godhavns-sagen. http://www.domstol.dk/KobenhavnsByret/nyheder/ domsresumeer/Pages/DomiGodshavns-sagen.aspx. Læst 17.10.2018.

2017 Domsresuméer. http://www.domstol.dk/oestrelandsret/nyheder/domsresumeer/ Pages/For\%C3\%A6ldelseafkravomgodtg\%C3\%B8relsefortortianledningafopholdp \%C3\%A5institutionenGodhavnfra1962til1965.aspx. Læst 17.10.2018.

Das, Veena

2007 Life and Words. Violence and the Descent into the Ordinary. Berkeley: University of California Press.

Edwards, Delyth

2017 Cultural, Autobiographical and Absent Memories of Orphanhood. The Girls of Nazareth House Remember. Oxford: Palgrave Macmillan.

Eriksen, Christina Toustrup

2017 Rædslerne fra barndommen hjemsøger dem stadig: Vi var bange, hver gang vi skulle i seng. TV2 Nyhederne, 19. marts. http://nyheder.tv2.dk/samfund/2017-0319-raedslerne-fra-barndommen-hjemsoeger-dem-stadig-vi-var-bange-hver-gangvi-skulle. Læst 30.10.2018.

Green, Anna

2004 Individual Remembering and "Collective Memory". Theoretical Presuppositions and Contemporary Debates. Oral History 32(2):35-44.

Jelin, Elizabeth

2003 State Repression and the Labours of Memory. Minnesota: University of Minnesota Press.

Jensen, Stine Grønbæk

2019 At åbne skuffen. Om tidligere børnehjemsbørns transformationer af selvet og den sociale verden gennem erindringsarbejde. Ph.d.-afhandling. Odense: Syddansk Universitet og Danmarks Forsorgsmuseum.

Kragh, Jesper Vaczy, Stine Grønbæk Jensen \& Jakob Knage Rasmussen

2015 På kanten af velfærdsstaten. Anbragte og indlagte i dansk socialforsorg 1933-1980. Odense: Syddansk Universitetsforlag

Murphy, John

2010 Memory, Identity and Public Narrative. Cultural and Social History 7(3):297-314. 
Nielsen, Jesper W.

2016 Der kommer en dag. Nordisk Film. https://www.kino.dk/film/d/de/der-kommer-endag. Læst 17.10.2018.

Nora, Pierre

1996 General Introduction. Between Memory and History. In: P. Nora (ed.): Realms of Memory. Rethinking the French Past. Bd. 1. Pp. 1-20. New Haven: Columbia University Press.

Ortner, Sherry B

2005 Subjectivity and Cultural Critique. Anthropological Theory 5(1):31-52.

Pettersen, Karen Sofie

$2011 \quad$ Anerkjennelse eller omfordeling som botemiddel for historisk urett? Handicaphistorisk Tidsskrift 26:55-69.

Rytter, Maria

2011 Godhavnsrapporten. Odense: Syddansk Universitetsforlag.

Rytter, Maria \& Jacob Knage Rasmussen

2015 The Godhavn Inquiry. In: J. Sköld \& S. Swain (eds): Apologies and the Legacy of Abuse of Children in "Care". Pp. 97-105. London: Palgrave Macmillan.

Simonsen, Eva \& Karen-Sofie Petterson

2015 The Politics of Apology. The Norwegian Case. In: J. Sköld \& S. Swain (eds): Apologies and the Legacy of Abuse of Children in "Care". Pp. 114-23. London: Palgrave Macmillan.

Skov, Rikke

2005 Drengehjemmet. DR tv-dokumentar.

Sköld, Johanna

2013 Historical Abuse. A Contemporary Issue. Compiling Inquiries into Abuse and Neglect of Children in Out-of-Home Care Worldwide. Journal of Scandinavian Studies in Criminology and Crime Prevention 14:5-23.

2015 Apology Politics. Transnational Features. In: J. Sköld \& S. Swain (eds): Apologies and the Legacy of Abuse of Children in "Care". Pp. 13-26. London: Palgrave Macmillan.

Tornbjerg, Ole

2015 Drengen fra Godhavn. København: Politikens Forlag. 